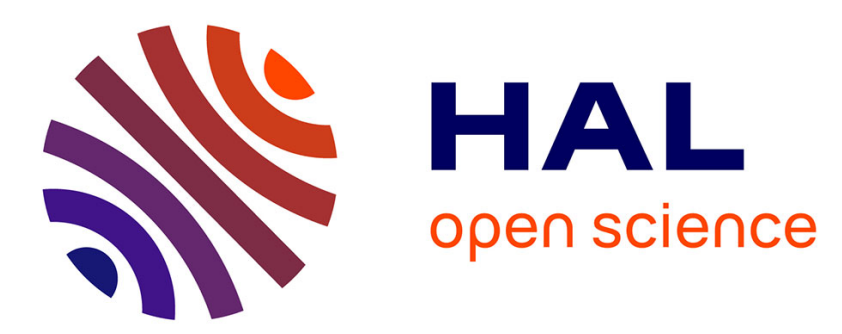

\title{
Origin of the carbon rich sliding interface in alkali containing matrix-SiC Nicalon fibre composites
}

\author{
E. Mouchon, Ph. Colomban
}

\section{To cite this version:}

E. Mouchon, Ph. Colomban. Origin of the carbon rich sliding interface in alkali containing matrix-SiC Nicalon fibre composites. Journal de Physique IV Proceedings, 1993, 03 (C7), pp.C7-1941-C7-1944. 10.1051/jp4:19937311 . jpa-00251956

\section{HAL Id: jpa-00251956 https://hal.science/jpa-00251956}

Submitted on 1 Jan 1993

HAL is a multi-disciplinary open access archive for the deposit and dissemination of scientific research documents, whether they are published or not. The documents may come from teaching and research institutions in France or abroad, or from public or private research centers.
L'archive ouverte pluridisciplinaire HAL, est destinée au dépôt et à la diffusion de documents scientifiques de niveau recherche, publiés ou non, émanant des établissements d'enseignement et de recherche français ou étrangers, des laboratoires publics ou privés. 


\title{
Origin of the carbon rich sliding interface in alkali containing matrix-SiC Nicalon fibre composites
}

\author{
E. MOUCHON and Ph. COLOMBAN ${ }^{*}$
}

ONERA-OM, BP. 72, 92322 Châtillon, France

* also at LASIR, CNRS, 2 rue Henri Dunant, 94320 Thiais, France

\begin{abstract}
The interfacial Nicalon Sic/Nasicon matrix reaction and its influence on the microand macroscopic mechanical properties have been studied by chemical analysis, EDX, SEM, microindentation, fibre tensile and composite flexural strength. Reaction mechanims and relationships with mechanical properties are discussed. An explanation of the origin of the " $\mathrm{C}$ " sliding interphase is proposed.
\end{abstract}

\section{INTRODUCTION}

To develop new engines in the fields of aeronautics and space requires materials with specific characteristics : lightness, high temperature, mechanical reliability and ability to withstand use in severe environments. Ceramic matrix composites with long woven fibres exhibit greater toughness owing to a specific micromechanism : a sliding fibre-matrix interface. If the fibre-matrix interface is too strong, a brittle fracture occurs through the fibres. If the fibre-matrix interface is weak, fibre-matrix decohesion takes place. A medium interface leads to optimal properties. This is obtained for example by $C$ or $B N$ film deposit before the matrix condensation in the CVI process. Previous electron microscopy analyses have demonstrated that the chemical reaction between Nicalon SiC fibres and molten alkali silicate matrix during the elaboration was large enough to provide a $C$ film $(1,2)$ But, the chemically changed volume is small $100 \mathrm{~nm}$ which makes the analysis and understanding difficult. We have developed a new process $(3,4)$ which allows the manufacture of multilevel composites without melting of the matrix. Refractory matrix composites can be obtained by low temperature sintering but the sintering time is lengthened (20-40 min, typically). Consequently, a thicker region (a few microns) results from the fibre-matrix reaction. Thus many techniques may be used to understand the fiber-matrix reaction. Our attention has been focused on Nicalon NLM $202 \mathrm{SiC}$ fibre-sodium silicozirconophosphate NASICON matrix composite using SEM, X micro-analysis and Vickers microindentation.

\section{EXPERIMENTAL}

The fabrication of 2D SiC Nicalon NLM 202 woven fabrics reinforced composites was previously reported (4,5). The process is based on the hydrolysis-polycondensation of alkoxides. This method allows the tailoring of both interface and matrix microstructures. The preparation takes place in three stages : i) impregnation of SiC fibre yarns of fabrics by an interface gel precursor (a liquid which becomes a gel, in situ), ii) deposition of a fine amorphous and reactive powder (a matrix precursor), iii) hot pressing of the doubly impregnated fabrics in a carbon mold.

For the elaboration of NASICON composites the oxide compositions of matrix and interface

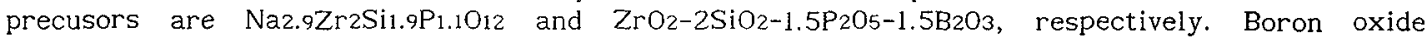
leads to the formation of liquid traces which promotes the densification, the Boron being then lost by evaporation during the hot-pressing dwell. Fibres are extracted from composites by $H F$ dissolution of the matrix. 


\section{RESULTS AND DISCUSSION}

SiC fibre-matrix interfacial reaction. The fibrous fracture observed in composites is usually explained by the presence of a graphitic carbon film at the SiC fibre-matrix interface $(1,2,6)$. However, the deposit of such a film by CVD at the SiC interface leads to a dissipative fracture (7). A $50-500 \mathrm{~nm}$ carbon film have also been evidenced at the interface between Nicalon fiber and alkali (or earth-alkali) containing matrix (Pyrex, LAS, CAS, ...) $(1,2)$. The continuality of this film is however not demonstrated. On the other hand, the absence of such a "large" carbon film was pointed out for SiC Nicalon/Mullite matrix composites (8).

Previous microanalysis investigations $(4,9)$ have shown that $\mathrm{Na}$ diffusion occurs within the fibre core in Nasicon matrix composites. Chemical analysis of extracted fibres and in situ EDX analysis give the same $\mathrm{Na} / \mathrm{Si}$ atomic ratio $(\sim 2 \%)$. A higher $\mathrm{Na}$ concentration $(\sim 3 \%)$ is measured for the fibres located at the woven fabrics limit, in contact during the elaboration cycle with the sodium- and boron-rich liquid sintering aid. This liquid results from the reaction between the B-rich interface precursor and the Na-rich Nasicon matrix. As shown in Fig. 1a, we observe a black contour around the fibre (retrodiffused electron mode). Microanalysis shows that the $P$ element replaces the $S i$ one and simultaneously the oxygen content is increased to satisfy the electric balance : a true scorce of carbon-rich sodium phosphosilicate is formed $(4,9)$.

The most reasonable assumption is that the oxycarbide second phase of SiC Nicalon fiber undergoes the following reaction.

$\mathrm{SiO} 4 x \mathrm{Cx}+\mathrm{yNa}^{+}+\mathrm{zP}^{5+} \longrightarrow \mathrm{Nay}\left(\mathrm{Si}_{1-z} \mathrm{Pz}_{2}\right) \mathrm{O}_{4-x+y / 2+5 / 2 z \mathrm{Cx}}$

This reaction needs to be oxygen balanced. Assumption can be made that oxygen results from partial dissociation of the oxycarbide phase, as follows. e.g. : $\mathrm{SiO}_{3} \mathrm{C} \longrightarrow \mathrm{SiO}_{2}+\mathrm{C}+\mathrm{O}$

These reactions explain the observation of glassy phase with carbon precipitates. The high dc conductivity measured on fibres extracted from Nasicon $\left(\sigma \mathrm{dc} \sim 10 \mathrm{Sm}^{-1}\right)$ composite indicates that the $C$ precipitates are roughly connected (4). Oxygen can also be provided by the matrix.

Relationship between interfacial reaction and mechanical properties. Micro-Vickers indentation confirms that the scorce is a glass $(\mathrm{Hv} \sim 5-6 \mathrm{CPa})$ whereas the $\mathrm{SiC}$ core retains the mechanical properties (Hv 25GPa) of unreacted fibre (9). Thus, in the composite the fibres can be classified in three types : a-fibres exhibiting no visible scorce at our resolution $(\sim 0,2 \mu \mathrm{m})$, b-fibres exhibiting a visible but small black contour $(\sim 1.5 \mu \mathrm{m})$, c-fibres exhibiting a large scorce such as shown in Fig. 1b. Micro-Vickers indentation gave also evidence that the formation of a visible scorce lowers both the interfacial shear stress and the sliding load threshold (9). The Fig. 2 shows the evolution of the three points flexural mechanical strength versus the duration and the temperature of the hot-pressing dwell. Highest values are obtained for composites sintered between 1035 and $1070^{\circ} \mathrm{C}$. The lowest open porosity ranges between 4 and $7 \%$. The minimum is however not correlated to the highest flexural strength. The dwell duration leading to the highest value is reduced when the dwell temperature increases. Determination of the relative proportions of the $a-, b-$ and $c-$ fibre types has been made by visual examination of composite polished sections. Results are given in Fig. 2c. We observe that the highest value corresponds to the highest proportion of $b-$ fibres. This is confirmed by the measure of the tensile strength of extracted fibres. Two kinds of Weibull distributions are evidenced, corresponding to a-, b- and c-fibres, respectively (Table 1 ). $a-$ and b-fibres keep roughly the tensile stength of SiC Nicalon fibres heated at the same temperature in $\mathrm{Nz}(2400-2100 \mathrm{MPa})$. The $a+b / c$ relative proportion is consistent with the visual determination.

Table I : Evolution of the tensile strength $(\sigma)$ of extracted fibres (gauge length $=10 \mathrm{~mm}$ )

\begin{tabular}{lllll}
\hline Dwell & Mean diameter & Fiber type & Number & $\sigma \mathrm{MPa}$ \\
\hline $1035^{\circ} \mathrm{C}-45 \mathrm{~min}$ & $15.9 \mu \mathrm{m}$ & $\mathrm{a}, \mathrm{b}$ & 18 & $2500 \pm 170$ \\
& & $\mathrm{c}$ & 12 & $1300 \pm 150$ \\
$1070^{\circ} \mathrm{C}-20 \mathrm{~min}$ & $15 \mu \mathrm{m}$ & $\mathrm{a}, \mathrm{b}$ & 19 & $2200 \pm 180$ \\
& & $\mathrm{c}$ & 13 & $1500 \pm 150$ \\
$1100^{\circ} \mathrm{C}-180 \mathrm{~min}$ & $13.5 \mu \mathrm{m}$ & $\mathrm{a}, \mathrm{b}$ & 8 & $2000 \pm 130$ \\
& & $\mathrm{c}$ & 19 & $1300 \pm 115$ \\
\hline
\end{tabular}



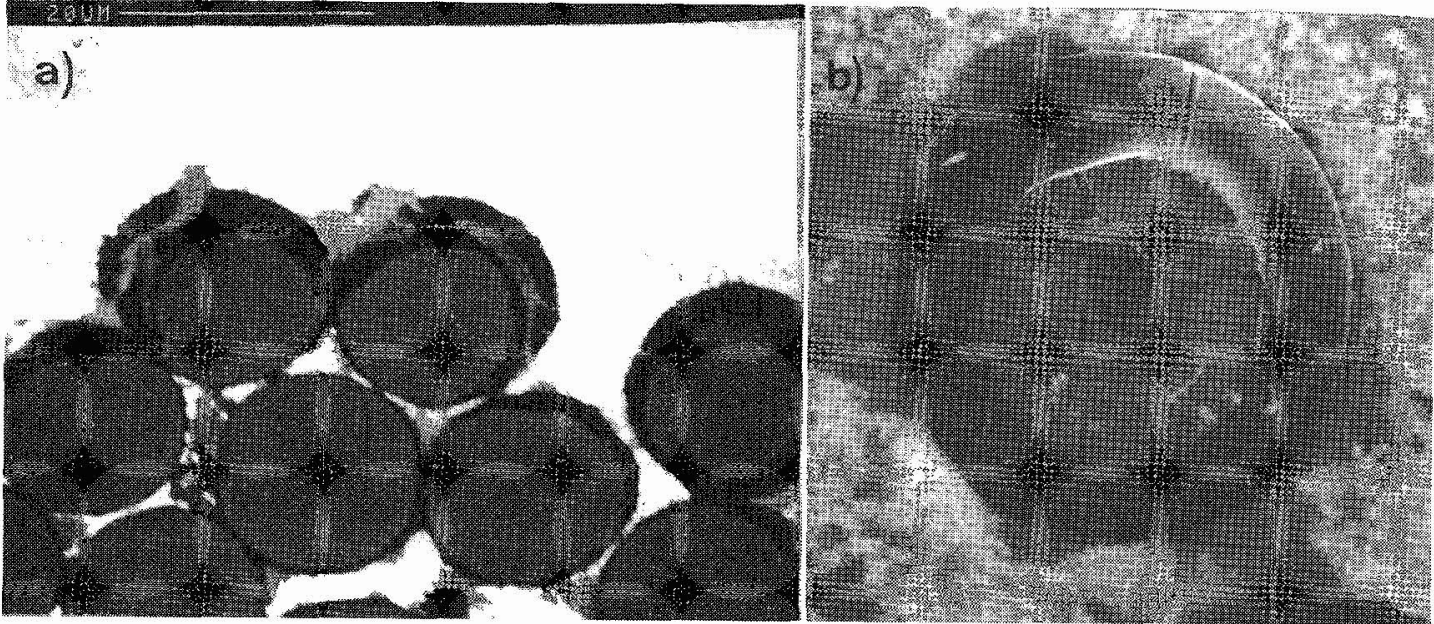

Fig. 1 : Photomicrographs of polished sections of a composite at the limit of the woven fabrics (a). The double decohesion observed after microindentation at the fibre core/scorce and scorce/matrix interfaces is shown in (b) (backscattered electron mode).

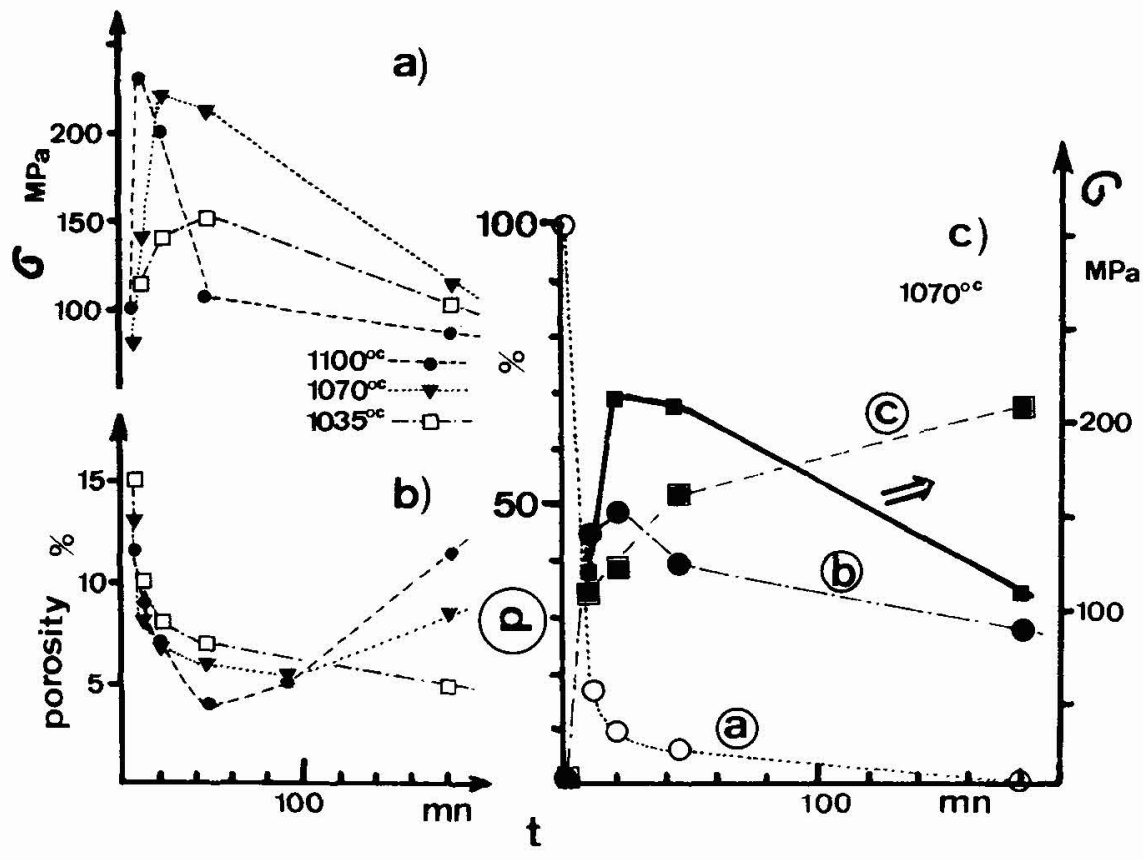

Fig. 2 : Relationship between densification and fibre scorce formation in Nasicon composites : 3 points flexural strength $(\sigma, a)$, open porosity (b) and relative proportions $(P)$ of the various fibres (c), as a fonction of the dwell duration ( $t$ in minutes) for various hot-pressing temperatures. The corresponding values of $\sigma$ are given. 


\section{CONCLUSION}

The "sliding" carbon interphase formed by reaction of SiC Nicalon fibre with alkali containing matrix is more complex than a simple $C$ film. An origin of the carbon precipitation can be found in the attack of the Nicalon oxycarbide second phase by $\mathrm{Na}$ (and P) elements leading to a glassy scorce. A moderate attack is necessary to obtain optimal mechanical properties. Sliding interface occurs both at the fibre/scorce and scorce/matrix limit. The replacement of $\mathrm{Si}^{(\mathrm{IV})}$ by $\mathrm{P}^{(\mathrm{V})}$ element at the fiber periphery is associated to the trapping of oxygen atoms, and to the carbon precipitation at the interfaces. On the other hand, when $\mathrm{Si}$ is replaced by $\mathrm{Al}^{\text {(III) }}$ element after reaction with a pure aluminosilicate matrix (e.g. mullite), the local oxygen excess could favour the departure of carbon by volatilization, leading to a carbon free sliding interface (8).

\section{REFERENCES}

[1] COOPER R.F, and CHYUNG K. J. Mater. Sci. 22 (1987) 3148.

[2] BLEAY S., SCOTT V.D., HARRIS B., COOKE R.G. and HABIS F.A., J. Mater. Sci. 27 (1992) 281.

[3] COLOMBAN Ph., Proc. 8èmes Journées Nationales sur les Composites (JNC-8), Nov.16-18 (1992) PALAISEAU, ALLIX O, FAVRE J.P. and LADEVEZE P. eds, AMAC, PARIS, (1992) 73.

[4] MOUCHON E., Thesis, University of PARIS VI, (1993).

[5] COLOMBAN Ph., MENET M., MOUCHON E., COURTEMANCHE G. and PARLIER M. Patent, ONERA FR, 91001237, EP92400235.5.

[6] CHERMANT J.C. and GOMINA M.J., Alloys and Comp. 188 (1992) 99.

[7] NASLAIN R., Proc. 8èmes Journées Nationales sur les Composites (JNC-8), Nov. 16-18 (1992), PALAISEAU, ALLIX O, FAVRE J.P. and LADEVEZE P. eds, AMAC, PARIS, (1992) p. 199

[81 BRUNETON E., COLOMBAN Ph. and MICHEL D., this Meeting.

[9] MOUCHON E., LAGRANGE J.L. and COLOMBAN Ph., Proc. 8èmes Journées Nationales sur les Composites (JNC-8), Nov. 16-18 (1992), PALAISEAU, ALLIX O., FAVRE J.P. and LADEVEZE P. eds., AMAC, PARIS, (1992), 85. 